\title{
Analyze the Effect of Customer Based Brand Equity on Consumer's Purchase Behavior: A Case of Branded Garments City Faisalabad
}

\author{
Muhammad Salman Arshad Arshia Ahmad \\ Lecturer at University of Central Punjab
}

\begin{abstract}
The purpose of this study was to examine the effect of brand awareness and brand loyalty on consumer's purchase behavior. The study enabled the researchers to realize the effect of brand awareness and brand loyalty on consumer's purchasing behavior. The area of this study was the garments industry of Faisalabad. The study was of primary nature and collected with the help of questionnaire from 300 respondents. In this research only purchasing behavior was taken as dependent variable and other two such as brand awareness and brand loyalty were taken as independent variables. To analyze the effects of these two independent variables on dependent variable multiple regression analysis was used as statistical technique. The finding of this study suggests that all two independent variables have significant impact on dependent variable individually and collectively.
\end{abstract}

Keywords: purchase behavior, brand awareness, brand loyalty, consumer, customer.

DOI: $10.7176 / \mathrm{DCS} / 9-8-02$

Publication date: August 31st 2019

\section{Introduction:}

Purchase intention depicts the impression of customer retention. There are certain functions of the brand cloth's which have a strong influence on the purchase intention of the customer's i.e. brand image, product quality, product knowledge, product involvement, product attributes and brand loyalty. This study will show the purchase behavior of the customers that how general public attract to make purchase of the branded cloth's and also reveal the important aspects which are quite necessary to capture the purchase intention of the customers. This research helps to categorize that among these aspects which factors have significant effect on the purchase intention of the patrons. In this wondrous world where penetration in the market in the presence of competitors is very problematic and challenging, it is very much important to determine the exact features which the consumer wants. It will help the marketers to focus on the features of the product that are significant and are positively correlated with purchase intentions of the customers. The customer driven approach is applied to find out the perception of users to have an exact idea about preference and desires. (Fandos \& Flavian, 2006)

The increase of buyer awareness has made buyers want to pay for their recognizable and valuable brand. Thus, it is important for businesses to create attraction in their brands to be in a better position than their competitors. This is evidence that the consumers distribute and always willing to acquire a product, so here the brand awareness is always a vital factor to manipulate the buying decisions and purchase intentions (Macdonald and Sharp, 2000).

Factors Affecting Consumer Buying Behavior:

Consumer buying behavior is influenced by the major three factors:

1. Social Factors

2. Psychological Factors

3. Personal Factors.

- Social Factors:

Social factors refer to forces that other people exert and which affect consumers' purchase behavior. These social factors can include culture and subculture, roles and family, social class and reference groups.

- Psychological Factors:

These are internal to an individual and generate forces within that influence her/his purchase behavior. The major forces include motives, perception, learning, attitude and personality.

- Personal Factors:

These include those aspects that are unique to a person and influence purchase behavior. These factors include demographic factors, lifestyle, and situational factors.

The word "Brand" owes its origin to the Norwegian word "brand" which means to burn. Farmers used to put some identification mark on the body of the livestock to distinguish their possession. Products are what companies make, but customers buy brands. Therefore marketers resorted to branding in order to distinguish their offerings from similar products and services provided by their competitors. Additionally, it carries an inherent assurance to the customers that the quality of a purchase will be similar to earlier purchases of the same brand. 
A brand is a name, term, sign, symbol or design or a combination of one seller or a group of sellers and to differentiate them from those of competitors. (Keller, 2003)

Investigations have also been extended further on the relationships between brand attachment and consumers' positive and negative behaviors which show different results both positive and negative. It means brand attachment does not have positive effects on consumer behavior only; it can lead to some negative outcomes also which is a new finding in modern research. Furthermore, the moderating effects of attachment styles on these relationships are also examined that empirically supports that brand attachment and attachment styles (i.e. anxiety attachment and avoidance attachment) are discrete. Companies should be alert of the consequences of building relationships with consumers who have a high level of attachment anxiety and/or avoidance (Japutra et al., 2018)

Though, only brand alertness and declared quality does not pledge of purchase and specifically repurchase intensions. The importance of brand loyalty cannot be ignored. Where brand awareness and perceived quality is necessary for the purchase of the brand, the loyalty is guarantee of purchase, brand loyalty plays a vital role in purchase, repurchase and switching behavior. So all three are significant for the purchase and purchase intentions (Oliver 1997).

Developing and properly managing brand equity has been emphasized as an important issue for most firms. Because, it can help firms to gain or increase their cash flow to the business, and make products differentiation in order to lead to competitive advantages (Yooet al., 2000; Aaker, 1991).

\section{Research Objectives:}

a. To examine the effect of brand awareness and brand loyalty on the consumer buying behavior in garments industry.

b. To study the relationship of independent variable on the dependent variable.

c. To identify the socio-economic factors of the respondents.

\section{Literature review:}

Molinillo et al., (2018) investigated in their research that makes two key contributions. First, we assess the validity of CBBE with tourism destinations. Second, we further examined validity of brand equity model in tourism domain. Hence, we contributed to the branding literature by advancing our knowledge of the relationship between brand awareness, brand satisfaction and brand loyalty for destinations. Brand satisfaction is identified with brand loyalty and an important component of brand equity.

Anselmsson et al., (2017) argued in their research that retailers are amongst the world's strongest brands, but little is known about retailer brand equity. In spite of their extensive use, we argue that current operational models are too abstract for understanding the uniqueness of the retail industry and too simplistic to understand the interrelationships among the dimensions in the retailer brand equity building process. This study contributes to the existing and largely generic retailer equity frameworks in three ways: first, by incorporating retail specific dimensions from the retailer image literature; second, by re-examining and developing the structures and relationships between the dimensions of retailer equity by testing alternative structures commonly used in the more general brand equity literature; and finally by creating a short and parsimonious scale for assessing retailer brand equity in different contexts.

Hatch et al., (2010) analyzed the fact that brand equity depends on the number of people with regular purchasing. The intensive discussion in the literature so far has a shade light on the values of brand equity for both consumers and the firm. For the consumers, brand equity were providing them within formation about the brand which influences their confidence during the purchasing process. And it was observed from such studies that there was a high tendency for consumers with good perceptions to buy from the same shop again than those with poor perceptions. Past purchasing experiences and familiarity with the brand could be attributable to the perceptions generated from the consumers.

Zhang, (2015) investigated in research entitled "The Impact of Brand Image on Consumer Behavior: A Literature Review" established that The concept "brand image" has drawn significant attention from academics and practitioners since it was put forward, because it played an important role in marketing activities. Although brand image was recognized as the driving force of brand asset and brand performance, few studies have elaborated on the relationship between brand image and brand equity. Based on the brand image theories, this study reviewed extant studies about the impact of brand image on consumer from perspective of customer equity. It also presented the shortcomings of current research and pointed out the trends for future study. The researcher held the opinion that brand equity came from the customers' confidence in a brand. The greater the confidence they place in the brand, the more likely they are willing to pay a high price for it. Specifically, this confidence stemmed from five important considerations: first, the brand performs its functions as designed; second, the social image is associated with purchasing or owning the brand; third, consumers' recognition and sentimental attachment with brand; fourth, the balance between the brand's value and its functionalities; fifth, consumers trust in the brand. 
Vermeulen et al., (2009) Argued that the potential consumers be aware of a product so that it can become one of the purchasing choices. That was due to the fact the product needs to enter the awareness set before it comes to the consideration set and an increase in brand awareness was favorable to a higher chance of entering the later set. In this way, brands with higher level of awareness would be more likely to be purchased.

Kotler \& Gertner (2002) researched that Brand awareness was the probability that, consumers were familiar about the availability and accessibility of a company's product and service. If an organization has a successful brand awareness it means that the products and services of the organization have a good repute in the market and simply acceptable. The awareness of the brand plays a significant role while purchasing a product or service and may have control on perceived risk evaluation of consumers and their level of assurance about the buying decision due to awareness with the brand and its uniqueness.

Lin (2015) argued in research "Innovative brand experience's influence on brand equity and brand satisfaction" claimed that Innovative brand experience is a particularly hot issue as it can deliver unique functional and emotional elements to build a strong relationship between the brand and its customers. The purpose of this study is to examine the relationships between innovative brand experience, brand equity and brand satisfaction in airlines. To this end, this study collects passenger survey data at Taiwan's Taoyuan International Airport and uses multiple regression analysis to examine the relationships among the research variables and identify the final performance. The results reveal that airline innovative brand experience has a positive impact on brand equity and brand satisfaction. The study confirms the benefits of innovative brand experience in the airline industry and in helping the airlines in the branding process and customer management.

Japutra et al., (2018) highlighted in their conducted research under the name "Positive and negative behaviors resulting from brand attachment" that brand attachment not only influences brand loyalty behavior but also three negative behaviors: trash-talking, schadenfreude and anti-brand actions. Moreover, the links between brand attachment and negative behaviors are strengthened when consumers have a high level of attachment avoidance. The study was based on a survey of 432 respondents, and the data were analyzed using the structural equation modelling approach, UK cities, ranging from Aberdeen to London. The participants were informed that they could win one of three Amazon vouchers if they participated in the survey. The respondents were asked to choose their favorites brand from a list of brands provided. The brands listed were diverse and from a mix of categories, including car manufacturers (e.g. Toyota and Volkswagen), electronics (e.g. Samsung and Apple), food and beverages (e.g. Cadbury and Coca-Cola), fashion retailers (e.g. Next and M\&S) and airlines (e.g. Virgin Atlantic and British Airways). Overall, 432 questionnaires were used for the analysis; sixty-one per cent of the respondents were women, 77 per cent were British and 26 per cent worked as professionals. Also, 37 per cent of the participants were in the age group of 16-34, 38 per cent of the participants were in the age group of 35-54 and the rest were in the age group of 55 and over. Furthermore, 54 per cent of the respondents had been using the brand that they chose for 10 years or more, 24 per cent purchased the brand several times a year and 34 per cent had purchased the brand less than a week ago.

Datta et al., (2017) investigated that brand equity can be measured using either consumer perceptions or sales. Consumer-based brand equity (CBBE) measures what consumers think and feel about the brand and had strong positive association with them and lead them to purchase behavior. Brand Asset Valuator data for 290 brands spanning 25 packaged good categories. The authors uncover a fairly strong positive association of SBBE with three dimensions of CBBE — relevance, esteem, and knowledge — but a slight negative correspondence with the fourth dimension, energized differentiation.

\section{Methodology}

This explains the detail of methodological procedures used to examine the relationship and effect of brand awareness and brand loyalty on purchasing behavior of consumers. Research design which includes the study population and data collection procedures, questionnaire to measure the variables and data analysis techniques are also explained. 


\subsection{Theoretical Framework}

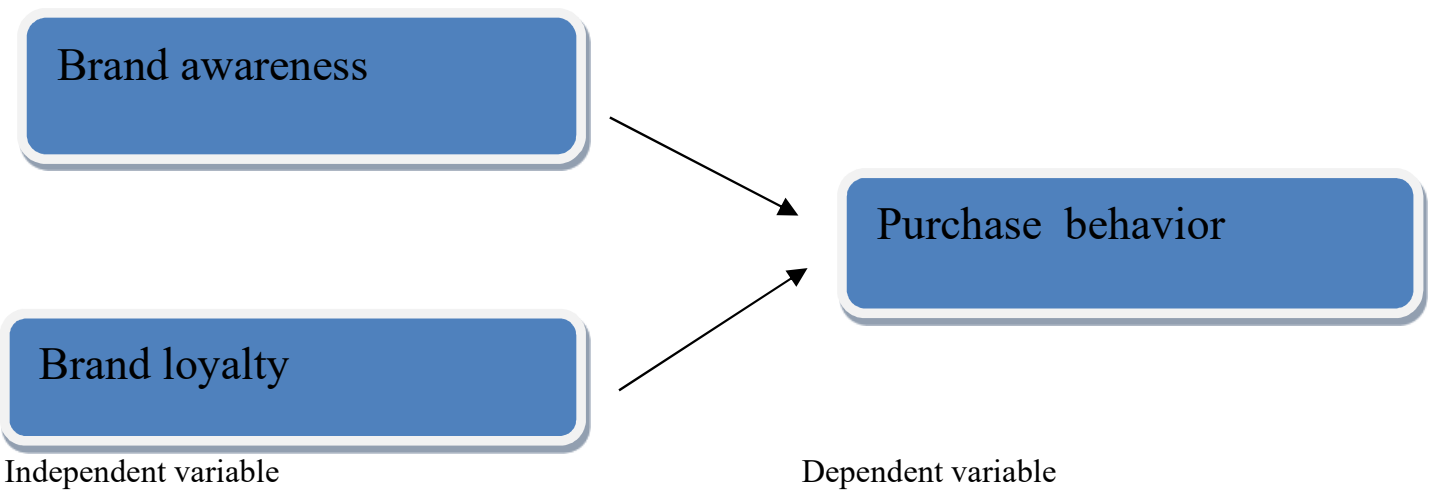

3.1.1 Reliability Analysis:

Dependent variable

Cronbach's (1951) coefficient alpha of the instruments was calculated separately. Following these values represent the mean of all possible split-half reliability coefficients. The results of these calculations are shown in following tables:

\begin{tabular}{|l|c|c|}
\hline \multicolumn{1}{|c|}{ Factor } & No. of item & Reliability \\
\hline Brand awareness & 6 & 0.710 \\
\hline Brand loyalty & 6 & 0.860 \\
\hline Purchasing behavior & 3 & 0.771 \\
\hline
\end{tabular}

The reliability of brand awareness scale observed 0.710 and brand loyalty scale is 0.860 . Whereas the reliability of the purchasing behavior scale observed 0.771 . These reliability estimates are acceptable and exploratory nature.

\subsection{Empirical framework:}

- Sample Area:

The nature of the problem deserves the much broader coverage of the area at national level but due to obvious limitations of the student researcher (time and financial resources) the research was restricted to Faisalabad city.

- Sample technique:

The Mall intercept technique was used. It is a method of data collection in which questionnaire in a shopping mall stop or intercept a sample of those passing by to ask them if they would be willing to participate in a research study; those who are agree questionnaire is conducted through them. The sampling technique used was convenience sampling technique.

Sample size:

The researcher selected convenience sampling method in order to get answer of people related to the brand awareness, brand loyalty and purchasing behavior. 300 questionnaires were distributed out of which 300 respondent positively respond the questionnaires.

\section{Data collection Method:}

An anonymous survey questionnaire was managed to collect response of the respondents. The questionnaires were handed over to the respondents with personal visits to different people Statistical Tools:

It usually shows about those techniques that we use to know about the relationship between dependent and independent variable and to check the significance level.

Statistical Package for the Social Science (SPSS-21) was used to analyze the statistical examination and qualification of results.

We used regression and correlation techniques in order check about the effects, relationship and significance level of independent variables on the dependent variable.

\subsection{Descriptive statistic:}

To analyze the outcome of the present research, to find out the percentage and the frequencies of the selected respondents, descriptive statistics were used.

\subsection{Regression:}

Regression analysis was used to quantify the impact of major advertisement related variable on the consumers' purchase intentions. Multiple regression analysis was used which gives a better interpretation of variables by estimating coefficients. The coefficient determines how strongly independent variables influence the dependent variable. The relationship between dependent and independent variable is given as;

$$
\mathbf{P}=\mathbf{f}\left(\mathbf{Z}_{\mathbf{i}}\right)
$$


$\mathbf{P}=$ Purchase.

$\mathbf{Z}_{\mathbf{i}}=$ Brand related attributes.

(P) Is the dependent variable (Purchase behavior). Categorical data of given independent variables were collected by using 5 point likert scale (strongly agree $=5$, agree $=4$, neutral $=3$, disagree $=2$, and strongly disagree $=1$ ).

The brand related attributes $\mathbf{Z}_{\mathbf{i}}$ are:

$\mathrm{Z}_{1}=$ Attitude towards brand awareness.

$\mathrm{Z}_{2}=$ Attitude towards brand loyalty.

\section{Construction of Hypothesis:}

To pursue the objectives of the research following hypotheses were constructed:

H1: Brand awareness has positive significant relationship with consumer's purchasing behavior.

H2: Brand loyalty has positive significant relationship with consumer's purchasing behavior.

H3: Brand awareness and brand loyalty have positive significant relationship with consumer's purchasing behavior.

\section{Results and Discussions:}

First data collection and then data analysis and deduction of results are the most important steps in social scientific research. Without these steps generalization and predictions cannot be made which is the objective of the research. The general objective of the study was to quantify the effect of main brand related and socio-economic variable on consumer's purchase intentions.

\section{Results and Discussion:}

Socio-Economic Characteristics of Respondents:

\section{Gender of the respondents}

\begin{tabular}{|l|l|l|}
\hline Gender & Frequency & Percent \\
\hline Male & 231 & 77.0 \\
\hline Female & 69 & 23.0 \\
\hline Total & 300 & 100.0 \\
\hline
\end{tabular}

Gender is considered as important indicators in the study of brand because products manufactured by the organizations are some specifically for females and some are for males. Therefore brand are made in distinctions with respect to gender by organizations because they males and females may have their own preferences towards the brand. The findings of the study revealed that 77.0 percent of the total respondents were male and 23.0 percent were females.

\section{Age of the respondents}

\begin{tabular}{|l|l|l|}
\hline Age (Years) & Frequency & Percent \\
\hline $15-20$ & 41 & 13.7 \\
\hline $21-25$ & 133 & 44.3 \\
\hline $26-30$ & 81 & 27.0 \\
\hline $31-35$ & 26 & 8.7 \\
\hline$>35$ & 19 & 6.3 \\
\hline Total & 300 & 100.0 \\
\hline
\end{tabular}

Age is very important demographic variable. It reflects the experience level of individuals. The more aged persons vary from the young ones in their attitudes and behaviors towards the brand and their purchase intentions. The study revealed that $13.7 \%$ of the total respondents were $15-20$ years of age, $44.3 \%$ were between $21-25$ years of age and $27.0 \%$ were between $26-30$ years of age, $8.7 \%$ were between $31-3$ years of age and $6.3 \%$ were $>35$ year of age.

Marital status:

\begin{tabular}{|l|l|l|}
\hline Marital status & Frequency & Percent \\
\hline Married & 103 & 34.3 \\
\hline Unmarried & 196 & 65.3 \\
\hline Total & 300 & 100.0 \\
\hline
\end{tabular}

Majority of the respondents that take part in study were un married frequency $196(65.3 \%)$ and frequency $103(34.3 \%)$ were married. 
Occupation:

\begin{tabular}{|l|l|l|}
\hline Occupation & Frequency & Percent \\
\hline Employee & 76 & 25.3 \\
\hline Own business & 84 & 28.0 \\
\hline Un employee & 140 & 46.7 \\
\hline Total & 300 & 100.0 \\
\hline
\end{tabular}

This table shows the occupation of the respondent in which mostly were un employees frequency $140(46.7 \%)$, some were own business frequency $84(28.0 \%)$ and further respondents were employee frequency $76(25.3 \%)$.

\section{Qualification:}

\begin{tabular}{|l|l|l|}
\hline Qualification & Frequency & Percent \\
\hline Matric & 49 & 16.3 \\
\hline Intermediate & 91 & 30.3 \\
\hline Graduation & 101 & 33.7 \\
\hline Master & 53 & 17.7 \\
\hline M.Phil. & 6 & 2.0 \\
\hline Total & 300 & 100.0 \\
\hline
\end{tabular}

The majority of the respondents $33.7 \%$ have studied Graduation, while $30.3 \%$ have studied Intermediate, $17.7 \%$ have Master's degree, and $16.3 \%$ have studied Matric, whereas $2.0 \%$ have M.Phil. The detail also indicates that entire workforce were literate.

Income level:

\begin{tabular}{|l|l|l|}
\hline Income level & Frequency & Percent \\
\hline 0 & 136 & 45.3 \\
\hline $10000-30000$ & 72 & 24.0 \\
\hline $31000-50000$ & 49 & 16.3 \\
\hline $51000-70000$ & 10 & 3.3 \\
\hline$>70000$ & 33 & 11.0 \\
\hline Total & 300 & 100.0 \\
\hline
\end{tabular}

This table indicates the income level of respondent. $45.3 \%$ of respondents were 0 income level, $24.0 \%$ were between the 10000-30000 income, $16.3 \%$ were between the $31000-50000$ income, $3.3 \%$ were between the 51000 70000 income and $11.0 \%$ were more then 70000 income.

Brand:

\begin{tabular}{|l|l|l|}
\hline Brand & Frequency & Percent \\
\hline Royal tag & 69 & 23.0 \\
\hline Bonanza & 101 & 33.7 \\
\hline Levi's & 52 & 17.3 \\
\hline Next & 44 & 14.7 \\
\hline Denizen & 34 & 11.3 \\
\hline Total & 300 & 100.0 \\
\hline
\end{tabular}

This table indicates the selected brand of respondent. $23.0 \%$ of respondents were selected Royal tag, $33.7 \%$ were selected Bonanza, $17.3 \%$ were selected the Levi's, $14.7 \%$ were selected the Next and $11.0 \%$ were selected the $11.3 \%$.

\subsubsection{Correlation Analysis:}

The correlation is described as dependence referred to any statistical relationship between two random variables or two sets of data. Correlation refers to any of a broad class of statistical relationships involving dependence. The correlation values ranging from 0.14 to point 0.17 are found significant at $5 \%$ and $1 \%$ level of significance respectively (Raja et al., 2004).

\section{Correlations}

Pearson correlation

\begin{tabular}{|l|l|l|l|}
\hline & Brand loyalty & Brand awareness & Purchase behavior \\
\hline Brand loyalty & 1 & & \\
\hline Brand awareness & 0.02 & 1 & \\
\hline Purchase behavior & $0.129^{*}$ & $0.384^{* *}$ & 1 \\
\hline
\end{tabular}

*.Correlationis significant at the 0.05 level (2-tailed).

**. Correlation is significant at the 0.01 level (2-tailed).

This table shows correlation among all variables. This table has shown that there is moderate but highly significant correlation of both independent variables (brand loyalty and brand awareness) with dependent variable (purchase behavior). The correlation table also explains that there is highly significant relationship among all the independent variables. 
Regression Analysis:

Regression results show the values of the coefficient of the determination and adjusted $\mathrm{R}$ square. It also describes the standard error of the variable.

\begin{tabular}{|l|l|c|c|c|c|c|}
\hline \multicolumn{7}{|c|}{ ANOVA $^{\mathrm{a}}$} \\
\hline \multirow{3}{*}{1} & Model & Sum of Square & Df & Mean Square & F & Sig \\
\cline { 2 - 7 } & Regression & 22.854 & 2 & 11.427 & 28.746 & $.000^{\mathrm{b}}$ \\
\cline { 2 - 7 } & Total & 118.062 & 297 & 0.398 & & \\
\end{tabular}

a. Dependent Variable: purchase-behavior

b. Predictors: (Constant), brand-awareness, brand-loyalty

Table 2 is labeled as ANOVA table. This table gives sum of squares along with respective DF (degree of freedom). The most important value in this table is F value. F-value is calculated as follows:

$$
F=\frac{\text { Regression Sum of Squares } / D F}{\text { Residual Sum of Squares } / D F}
$$

As indicated from the formula, F-value represents the ratio of explained variance and unexplained variance. A high F-value is, therefore, desirable. The significance of F-value is established by looking at associated $\mathrm{p}$ value. In this research, the value of $F$ is 28.746 which is significant $(p<0.05)$. The F-Value indicates overall significance of the regression model. A significant value of $\mathrm{F}$ indicates that regression model is significant as a whole and independent variables significantly predict dependent variable.

\section{Coefficients}

\begin{tabular}{|l|l|l|l|l|c|c|}
\hline \multirow{2}{*}{ Model } & \multicolumn{2}{|l|}{ Unstandardized coefficient } & $\begin{array}{l}\text { Standardized } \\
\text { coefficient }\end{array}$ & \multirow{2}{*}{ Sig } \\
\cline { 3 - 7 } & & $\mathrm{B}$ & Std. Error & Beta & & \\
\hline \multirow{3}{*}{1} & Constant & 1.610 & 0.369 & & 4.363 & .000 \\
\cline { 2 - 7 } & Brand loyalty & 0.137 & 0.060 & 0.122 & 2.288 & .023 \\
\cline { 2 - 7 } & Brand awareness & 0.499 & 0.069 & 0.381 & 7.181 & .000 \\
\hline
\end{tabular}

a. Dependent Variable: purchase-behavior

Table 3 is labeled as coefficients. This table represents constant and regression coefficients for independent variable(s). The coefficients are unstandardized as well as standardized. The coefficients are associated with their respective standard errors and t-values. The value of un standardized regression coefficient shows the amount of change in dependent variable that is brought upon by one unit change in independent variable. In this research, the value of un standardized coefficient for brand loyalty is 0.122 and brand awareness is 0.381 . This values shows that one unit change in brand loyalty and brand awareness will bring 0.122 and 0.381 units respectively change in perceived purchasing behavior. According to the table, coefficient of brand loyalty and brand awareness are significant as t-values are 2.288 and 7.181 respectively which are significant $(\mathrm{p}<0.05)$. The positive sign shows that brand loyalty and brand awareness have positive impact on perceived purchasing behavior, representing thereby, that an increase in brand loyalty and brand awareness will bring an increase in perceived purchasing behavior.

\section{Discussion}

Both independent variables brand awareness and brand loyalty have positive and significant impact on purchasing behavior. It is also concluded that higher level of brand awareness is the predictor to the higher the purchasing behavior. Similarly, brand loyalty is also a good and positive predictor to the higher the purchasing behavior. Purchasing behavior of consumers increases as when brand awareness and brand loyalty increases.

\section{Problems faced by respondents}

The respondents were asked by open ended question if they wanted to state about anything about branded garments in Faisalabad. The response was collected by the following question:

Do you want to state anything about branded garments in Faisalabad (Pakistan)?

There were various views stated by the respondents in this context. The most important and prominent issues faced by the consumers related to branded garments are as follow:

\section{- Repetition Frequency}

The $8.3 \%$ respondents expressed that mostly in Faisalabad the brand repetition frequency is very extensive. Most of the brand when repeated extensively creates the negative thoughts about the product. However they remember the product through repetition but it irritates them.

\section{- Less information about brand}

One of the problems faced by the respondent was that the less information about brand. They required more information in the their brands which can help them to evaluate the quality of the product. 
- Not to educate consumers

The respondents also stated that the brands made in the Pakistan are not for the purpose to educate the consumers about the products. The knowledge brand is only for the reason to attract the consumer through different means and methods.

- Less innovative

The brand in Pakistan is done through olds techniques. There is no newness and innovativeness in brand. Most of the brands are copied from the Indian brands. According to them they are bored by old techniques.

- False advertising

According to respondents some brand advertisements done in Pakistan are false. Most the local products of the company take advantage of the advertisement and mislead the consumers. Through this they buy those products which are of low quality.

\section{Summary and conclusion:}

This chapter explains and includes the objective of study, methodology adopted, major features of the results. Further policy implication and recommendations for the future research will be explained.

Now a day the perception of people about purchasing becomes different. Everyone wants to purchase branded things even tooth brush, shoes and also in garments. So that the purchase behavior of consumer's about branded garments change day by day. Consumer's purchase behavior affected brand awareness and brand loyalty. To enhance the purchasing intension towards their brands they must be provided the awareness of their brand to the consumer's So, that the consumer's becomes loyal to their brand because highly positively relationship among the brand loyalty and brand awareness towards purchase behavior of consumer'.

\section{Conclusions}

- First, all the correlation analysis indicates that correlation coefficient were positive and significant.

- Second, the regression test was use applied to check the cause and effect relationship of all independent and dependent variable individually. From the results, it was explained $16.2 \%$ variation in purchasing behavior due to brand awareness and brand loyalty.

- So, it is concluded from all findings and discussion that all independent variables (brand awareness and brand loyalty) have individually and collectively positive and significant impact on purchasing behavior. It is also concluded that higher level of brand awareness is the predictor to higher the purchasing behavior. Similarly, brand loyalty is also a good and positive predictor to higher the purchasing behavior. Purchasing behavior increases as and when brand awareness and brand loyalty increases.

\section{Recommendations:}

- This study was conducted only in Faisalabad, Pakistan. So, further research can be made on other cities of Pakistan.

- Most of the studies of purchasing behavior have asserted to highlight positive outcomes, such as increase awareness and loyalty among purchasing behavior of consumers. Negative outcomes have also been brought to light. Negative outcomes may also involve effects on innovation and creativity from and fashions and brands point of view.

- The major findings of this research show that increase in brand awareness and brand loyalty are connected to improve the purchasing behavior. Many positive organization commitment university administrations should consider for management practices that may increase the organizational commitment in employees.

- In an increasingly competitive market, retention of a customer is possible only through better service. Marketers will require devoting to more efforts to understand the customer view of quality and convenience. Marketers should do regular research to find this fact.

\section{Limitations:}

- As the research based on primary data and all the data was collected with the help of questionnaire. While random selection from the entire malls and shopping centre were made as well as questionnaire were given to those consumers who agreed to respond willingly.

- The consumers were very reluctant to answer the question and the response may be biased.

\section{References}

Anselmsson, J., Burt, S., \& Tunca, B. (2017). An integrated retailer image and brand equity framework: Reexamining, extending, and restructuring retailer brand equity. Journal of Retailing and Consumer Services, 38, 194-203. 
Datta, H., Ailawadi, K. L., \& van Heerde, H. J. (2017). How well does consumer-based brand equity align with sales-based brand equity and marketing-mix response?. Journal of Marketing, 81(3), 1-20.

Ekinci, Y. (2018, June). A MODEL OF CONSUMER BASED BRAND EQUITY FOR HOLIDAY DESTINATIONS. In 8th ADVANCES IN HOSPITALITY AND TOURISM MARKETING AND MANAGEMENT (AHTMM) CONFERENCE (p. 830).

Fandos, C., \& Flavián, C. (2006). Intrinsic and extrinsic quality attributes, loyalty and buying intention: an analysis for a PDO product. British food journal, 108(8), 646-662

Hatch, M. J., \& Schultz, M. (2010). Toward a theory of brand co-creation with implications for brand governance. Journal of Brand Management, 17(8), 590-604.

Keller, K. L. (2003). Brand synthesis: The multidimensionality of brand knowledge. Journal of consumer research, 29(4), 595-600.

Kotler, P., \& Gertner, D. (2002). Country as brand, product, and beyond: A place marketing and brand management perspective. Journal of brand management, 9(4), 249-261.

Molinillo, S., Ekinci, Y., Japutra, A., \& Turnbull, S. (2018). ASSESSING VALIDITY OF CONSUMER-BASED BRAND EQUITY MODELS FOR TOURISM DESTINATIONS. In Proceedings of the Travel and Tourism Research Association Conference (pp. 26-28).

Pitta, D. A., \& Prevel Katsanis, L. (1995). Understanding brand equity for successful brand extension. Journal of consumer marketing, 12(4), 51-64.

Macdonald, E. K., \& Sharp, B. M. (2000). Brand awareness effects on consumer decision making for a common, repeat purchase product:: A replication. Journal of business research, 48(1), 5-15.

Oliver, C. (1997). Sustainable competitive advantage: combining institutional and resource- based views. Strategic management journal, 18(9), 697-713.

Vermeulen, I. E., \& Seegers, D. (2009). Tried and tested: The impact of online hotel reviews on consumer consideration. Tourism management, 30(1), 123-127.

Yoo, B., Donthu, N., \& Lee, S. (2000). An examination of selected marketing mix elements and brand equity. Journal of the academy of marketing science, 28(2), 195-211. 